\title{
The Vital Entrepreneurial Learning Organization: A Corporate Mindset for Entrepreneurial Change Management
}

\author{
Bernd Peter Platzek1, Leon Pretorius²and Dietmar Hans Winzker ${ }^{3}$ \\ Department of Engineering and Technology Management \\ University of Pretoria, Lynnwood Road \\ Pretoria SA 0002, South Africa \\ 1platzek@hs-weingarten.de \\ ${ }^{2}$ leon.pretorius@up.ac.za \\ ${ }^{3}$ dwinzker@iafrica.com
}

\begin{abstract}
A globally competitive technology business environment requires a dual perspective for entrepreneurial change management to secure long-term and short-term vitality in mature organizations. Entrepreneurial organizations should shape the environment-organization relation and pursue entrepreneurial activities in new businesses and in existing businesses to integrate efficiency, innovation and adaptation. The presented concept of a vital entrepreneurial learning organization describes a systematic theoretical framework for firm-level entrepreneurship in dynamic environments. The theoretical constructs developed on theoretical exploration are: nine design elements of holistic intrapreneurship, three entrepreneurial tasks and process model, role model for the entrepreneurial organization, conceptual framework of the business environment, qualitative systems model for entrepreneurial change management, and five organizational learning elements. These theoretical building blocks provide new insights into the nature of holistic intrapreneurship.
\end{abstract}

Keywords: Entrepreneurial orientation; holistic intrapreneurship; entrepreneurial tasks and roles; global business environment; entrepreneurial change management and learning.

\section{Introduction and Research Method}

The aim of this paper is to present a concept of a vital entrepreneurial learning organization (VELO) that describes a systematic theoretical framework for firmlevel entrepreneurship in dynamic environments. This concept is developed using a system thinking approach supported by detailed literature and bibliographic review of some authoritative sources on corporate entrepreneurship taking a holistic view of the topic. 


\subsection{Entrepreneurial orientation and dual perspective as an imperative for organizational vitality in dynamic business environments}

The changes in the business environment call for a rethink in mature organizations about management concepts and organization architecture required to grow and secure long-term vitality [Greiner (1998); Hamel (2006)]. Adaptability is needed to be simultaneously innovative towards exploring new opportunities while exploiting established businesses [March (1991); Birkinshaw and Gibson (2004)]. To be such an ambidextrous organization [O'Reilly III and Tushman (2004)] - - - exploring the new while exploiting the old business concepts - - balancing strategy, process, structure and skill issues are needed [Kanter (2006)]. Organizations with a more hierarchical structure and managerial perspective have to simultaneously adopt a more en-trepreneurial perspective with complementary and networked [Kotter (2012)] struc-tures. As a result, periods of incremental change marked by an increasing alignment among strategy, structure, people, and culture are punctuated by revolutionary change that needs a simultaneous shift in strategy, structure, people, and culture [Tushman and O'Reilly III (1996)].

Market-driven and market-driving behavior reflects a dual perspective: market orientation with reactive innovations and entrepreneurial orientation with proactive innovations [Schindehutte et al. (2008); Hills et al. (2008); Kim and Mauborgne (2004)]. Consequently, to successfully compete in new and mature markets and to master the challenge of complexity and change management a holistic concept of corporate entrepreneurship to find the essential entrepreneurial orientation [Miller (2011); Covin and Lumpkin (2011); Covin and Wales (2012)] is vital. So, a strong focus on a continuous interaction with the external business environment through entrepreneurial activities and self-regulating organizational dynamics move the organization's life cycle forward [Platzek et al. (2010)]. Balanced entrepreneurial activities for innovation, adaptation and efficiency create learning processes [Schein (1995)] for strengthening entrepreneurial orientation and would have to be pursued if organizations are to survive in the global and intensively competitive business environment [Baumol (2004)].

This paper describes a new theoretical concept of firm-level entrepreneurship [Zahra et al. (1999)] to grasp the right balance in exploring and exploiting in established and new businesses and to take a necessary dual perspective for entrepreneurial change management. A corporate mindset is defined by theoretical building blocks for a VELO in a dynamic business environment [Platzek et al. (2011)]. This concept helps to understand the big picture of an emerging business arena to shape the interaction of the VELO with today's global business environment.

\subsection{Research method}

The ensuing design concept with theoretical constructs of a VELO is developed via theoretical analysis, conceptual analysis and synthesis. This research enables a holistic understanding of intrapreneurship and is done on the basis of a theoretical 
eclectic literature study. Fundamental economic and management theory concepts as well as systems thinking serve as a theoretical frame of reference for the research method in this paper.

The connection between the economic concept of the corporate actor [e.g. Homann and Suchanek (2005)], the role concept from the discipline of sociology [e.g. Biddle and Thomas (1966)] and systems thinking [e.g. Jackson (2000)] allow the creation of a role model for the VELO. This role model can be specified for various cultural frameworks and specific contexts to design a VELO in practice.

The exploratory research conducted in this paper then results in a conceptual framework of the dynamic end state of the VELO, the three central entrepreneurial tasks, the role model for the entrepreneurial firm, the framework for the business environment, the qualitative model for the interaction between organization and environment, and the five learning elements for strengthening entrepreneurial orientation. The concept of the VELO thus focuses on the entrepreneurial action of the organization as a whole in symbiosis with the external environment. As a result, the ambidextrous VELO as an open system combines a managerial mindset with an entrepreneurial mindset to exploit established businesses and to explore new businesses (see Fig. 1).

However, this presented view distinguishes the managerial and entrepreneurial mindset [see Drucker (1985); Lumpkin and Dess (1996); Narayanan and Fahey (2004)] from a theoretical perspective. The managerial mindset is more reactive, task-oriented and open to internal events and has a special focus on established business, planned strategy, efficiency in operations, and controlling. The entrepreneurial mindset is more proactive, creative, and open to external events and has a special focus on new business, emergent strategy and self-organizing, innovation and opportunities. In practice both mindsets should be used in an integrated way and at all levels of the company system. Therefore, the best balance of both perspectives and the entrepreneurial intensity [Morris et al. (2008)] to secure vitality depends on the character of the business environment.

Against this background, the concept and the building blocks of a VELO will be presented in the following sections.

\begin{tabular}{|c|c|c|}
\hline & Managerial mindset & Entrepreneurial mindset \\
\hline & Performance drive & Entrepreneurial drive \\
\hline \multirow[t]{4}{*}{ Orientation } & Navigating modus & Creative modus \\
\hline & Reactive adaptation & Proactive adaptation \\
\hline & Strategic thinking from small picture & Entrepreneurial thinking from big picture \\
\hline & Task and controlling & Opportunity and vision \\
\hline \multirow[t]{3}{*}{ Focus } & Efficiency and improvements & Innovation and change \\
\hline & Planned managerial strategy & Emergent entrepreneurial strategy \\
\hline & Established business & New business \\
\hline
\end{tabular}

Fig. 1. Corporate mindset for entrepreneurial change management and dual perspective. 


\section{The Dynamic End State of the VELO: Conceptual Framework for Holistic Intrapreneurship}

Various aspects for the description of intrapreneurship can be identified from the literature. The fundamental entrepreneurial task is defined by the identification and pursuit of opportunities and risks [e.g. Drucker (1985); Ireland et al. (2009)] together with the use of company resources for entrepreneurial activities [e.g. Hamel and Prahaland (1994)] that secure competitiveness and vitality [e.g. Guth and Ginsberg (1990); De Geus (2002)].

The economic and management theory define different main themes in terms of the implementation and design of intrapreneurship. Some approaches demand a collective effort [e.g. Reich (1987)] with a holistic orientation [e.g. Senge (2006)], others see strong entrepreneurial personalities [e.g. Pinchot (1988)] as the driving force for intrapreneurship [Bouchard and Basso (2011)]. Numerous approaches focus on the internal design of the entrepreneurial organization and process [e.g. Covin and Slevin (1991); Hornsby et al. (1993)], others put the emphasis on innovation and optimization [e.g. Abell (1993); Morris et al. (2008)], while others see the products, markets and technology as being central [e.g. Block and MacMillan (1995)]. In all of this, it is clear that entrepreneurial activities should not only be pursued in new businesses, but also in existing businesses if the adaptability of the entrepreneurial organization and its theory of business are to be secured [Drucker (1994)].

To integrate the several aspects found in literature, pattern recognition [e.g. Vester (2007)] is applied and nine central design elements of intrapreneurship as a theoretical construct are identified and deduced to integrate a managerial and entrepreneurial mindset in the VELO (see Fig. 2).

The nine design elements are identified in a qualitative theory-based exploration via reflection, comparison, and integration of the implications for the role of intrapreneurship in a global business environment. Thus, the nine design elements define a coherent framework to relate and integrate the different concepts from literature and to describe the key aspects of holistic intrapreneurship.

The starting point and first element is a definition of the basic entrepreneurial task: entrepreneurial organizations must identify and process opportunities and risks in the internal and external business environment. Here, strong implementation skills are important if entrepreneurial activities are to be realized in existing and new businesses using both existing and future resources and competencies [Ulrich and Smallwood (2004); Garvin and Levesque (2006)]. The second element defines the entrepreneurial fields of operation in the business environment: entrepreneurial opportunities and risks can be identified in both the general macro- and specific micro-environment [Fahey and Narayanan (1986); Porter (2008)]. The third element is the internal business environment to create space for corporate entrepreneurship. The entrepreneurial dynamic of an organization is determined by the entrepreneurial mission, vision, strategy, structure and culture, as well as by the entrepreneurial actors, the resources and competencies [see e.g. Covin and Slevin (1991)].

The fourth element specifies the three entrepreneurial strategy fields as innova-tion, adaptation and optimization [e.g. Hammer (2004); Child (2005); Kanter (2006)] to create a resilient organization. Entrepreneurial decision fields based 


Element 1:
Entrepreneurial task
Identify and process
opportunities and risks
in existing and new businesses.

Element 4:
Entrepreneurial strategy fields
Agreement
innovation
adaptation
optimization

\section{Element 7:}

Orientation towards vitality

Pursue short and long term potential

Make use of life cycle and positioning as mature organization:

Continuous renewal, adjustment of organization boundaries

Element 2:
External entrepreneurial
operation fields
Analyze
general macro environment
industry
local and global factor and
product markets
as sources of opportunities

\author{
Element 3: \\ Entrepreneurial \\ organization design \\ Analyze and develop \\ entrepreneurial mission, vision \\ and strategy, \\ structure and culture \\ resources and competencies
}

\section{Element 5:}

Entrepreneurial decision fields

\section{Define}

buy-side

in-side

sell-side

\section{Element 6: \\ Entrepreneurial action fields \\ Process \\ product \\ market \\ technology \\ business model}

Element 8:
Global orientation
Global playing fields
Global strategies
Global and local perspectives
Use of cultural differences and
learning from global activities

Element 9:

\section{Holistic orientation}

Identify system structures, patterns and shared mental models, understand and use harmonization of objectives and interests within the organization Symbiosis with environment Internal and external synergies

Fig. 2. Nine central design elements of holistic intrapreneurship.

on fundamental economic questions [e.g. Forgang and Einolf (2007)] are the fifth element and relate to the buy-side (input), the sell-side (output) and the inside (throughput). The sixth element comprises the entrepreneurial action fields of product, market, technology and business model innovation [Block and MacMillan (1995); Schinde-hutte et al. (2008); Hills et al. (2008); Johnson et al. (2008)].

The remaining elements determine the entrepreneurial alignment of the organization. Orientation towards vitality is the seventh element and requires the pursuit of short-term and long-term success potential [De Geus (2002)]. By carrying out entrepreneurial activities, a continuous renewal of the organization is achieved and the boundaries and networks of the organization are continuously adjusted. The eighth element is global orientation, which widens the field of play for entrepreneurial activities and takes into consideration the global dynamics of the markets and cultural differences in terms of how opportunities and risks are identified and processed [Gupta and Govindarajan (2002)]. The ninth element, holistic orientation [e.g. Jackson (2006)], makes it possible to have internal and external synergies, internal harmony between the individual actors and the organization, as well as a symbiosis of the entrepreneurial organization with the external environment.

The nine central design elements can be used as a framework to give a clear picture of relevant perspectives of holistic intrapreneurship in today's global business environment. It is also a starting point for further analysis on the VELO in the next sections. 


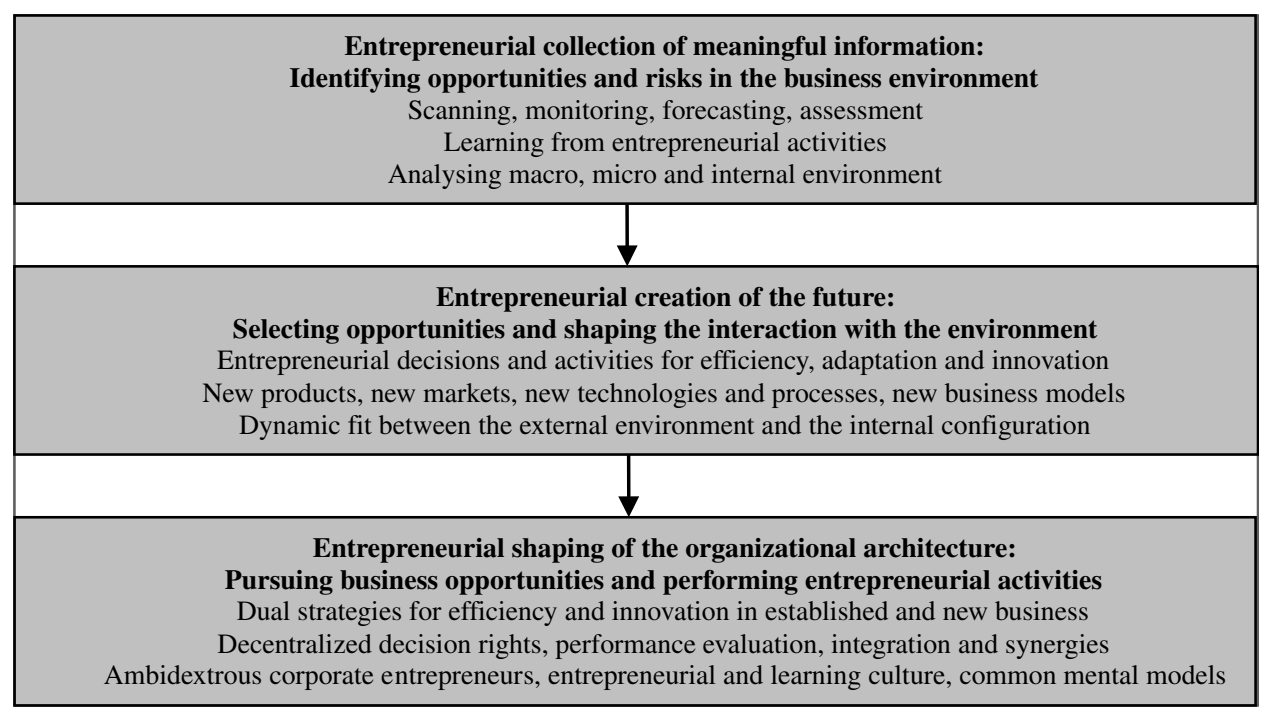

Fig. 3. Three tasks of the VELO.

\section{Entrepreneurial Tasks and Design Principles}

The nine design elements define a conceptual framework of the dynamic end state of the VELO. Three entrepreneurial tasks (see Fig. 3) as a theoretical construct consolidate these design elements and give orientation to push the VELO forward: entrepreneurial collection of meaningful information from the business environment as a basis for identifying opportunities and risks, entrepreneurial shaping of the future, in order to determine the interaction between the entrepreneurial organization and the environment as well as the entrepreneurial shaping of the organization (for making the organizational architecture adaptable) and development of a selfdynamic for optimization, adaptation and innovation. The collection of meaningful information and learning processes make it possible to define the goals of a VELO in the context of shaping the entrepreneurial future. The entrepreneurial organization design determines the order and structure as well as the processes for the implementation of entrepreneurial decisions and activities for the achievement of efficiency, adaptation, and innovation.

It determines the flexible framework for the creation and implementation of ideas together with an efficient input-output transformation in the operational system. Change in the business environment determines change in the organization. In particular, changes in the industry environment affect the opportunities and risks of the organization and thus the development and implementation of the mission and strategy. Changes in the general macro-environment have an effect on sectors as well as on the mental models of the actors and the organization. They thus influence the entrepreneurial self-dynamic in existing and new businesses. Controlled entrepreneurial strategy develops in a planned and emergent way [Mintzberg (1991)] and shows itself in the entrepreneurial activities realized. 


\section{Design principles for the vital entrepreneurial learning organization}

1. Filter early signals about changes in the business environment and share individual knowledge

2. Develop common mental models about the business environment and think in scenarios and alternative futures

3. Use collective intelligence, constructive conflicts, differing views and cultural differences

4. Learn from entrepreneurial activities and experiments

5. Make entrepreneurial decisions in existing and new business at all levels

6. Take rapid action to shape opportunities and change as well as mastering risks and crises

7. Achieve best match of (future) resources and competencies with (future) opportunities

8. Pursue planned and emergent dual strategies for optimization and renewal; short and long-term viability; flexibility and stability in operations; decentralized responsibility and central coordination

9. Design structures and decision rights for efficiency, adaptation, innovation, integration between organization and environment, individuals and organization, groups and units

10. Design entrepreneurial culture for orientation, coordination, and change

Fig. 4. Design principles for entrepreneurial collection of meaningful information, entrepreneurial shaping of the future and organization.

These activities are the result of reflecting current and future opportunities and threats against the current and future resources and competencies of the organization. The achievement of the three central tasks of an entrepreneurial organization, based on the division of labor and job assignment, must be specified companyspecifically. For the organization as a whole however, general design principles (see Fig. 4) can be defined [see Platzek et al. (2011)].

In the next section, three theoretical constructs for holistic intrapreneurship are presented. A role model is developed which can steer the entrepreneurial organizational design. The framework for the specification and analysis of the business environment can support entrepreneurial collection of meaningful information. The qualitative systems model describes the fundamental interaction between the entrepreneurial organization and the environment for shaping the entrepreneurial future on aggregated levels.

\section{Theoretical Constructs for the VELO}

The theoretical framework [Platzek et al. (2010)] of the VELO consists of the role model of an entrepreneurial organization (see Sec. 4.1), a conceptual framework for the global business environment (see Sec. 4.2), together with a systems model of a vital entrepreneurial organization in interaction with the global business environment (see Sec. 4.3) and five elements for individual and organizational learning (see Sec. 4.4). The theoretical building blocks for holistic intrapreneurship describe the role of intrapreneurship in a global business environment and also give a theoretical design framework that can serve a specific VELO in a specific (cultural) context. 


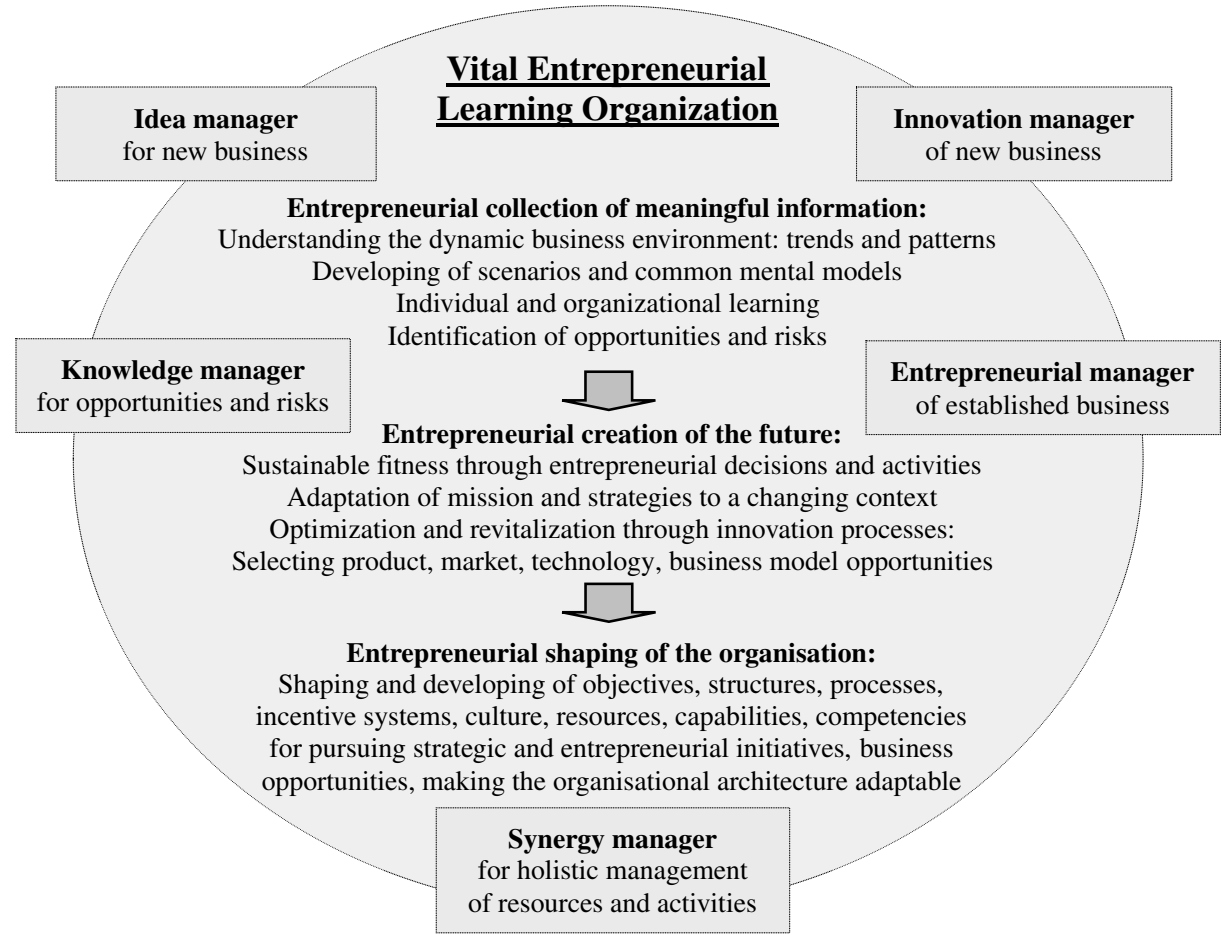

Fig. 5. Role model for the VELO.

\subsection{Role model of the VELO}

The role model (see Fig. 5) captures several basic roles of intrapreneurship identified in the relevant work of various authors and in the view of the global competitive business environment in an integrative framework. The role model gives a framework to perform the three entrepreneurial tasks and gives a general orientation to create the VELO in a specific way and context. The entrepreneurial roles that have to be fulfilled holistically by the entrepreneurial organization as a corporate actor [see Homann and Suchanek (2005)] are identified and described.

The implementation of these roles using division of labor and job assignment takes place for individual entrepreneurial organizations in a way that is dependent on the specific situation. The company-specific sharing of roles and tasks [Platzek et al. (2013)] between all members of the organization requires a systematic and holistic selection and use of specific talents, an entrepreneurial development of the personnel portfolio [Roffe (1999)] and support for cooperative and entrepreneurial teams and team members.

The knowledge manager collects and analyzes systematically relevant information about the internal [e.g. Dess and Lumpkin (2003); Porter (2004); Hitt et al. (2005)] and external business environment [e.g. Fahey and Narayanan (1986); Senge (2006); Porter (2008)] to create, identify, share, apply, and store knowledge [e.g. Heisig (2009)] about customers, suppliers, markets and industries, competitors as well as mental models, trends and scenarios about the general macro-environment. 
This knowledge helps to identify opportunities and risks for new businesses and in established businesses.

Individual and organizational learning from entrepreneurial activities [Block and MacMillan (1995); Argyris (1999)] and crisis [De Geus (2002)] also creates knowledge and future options. The knowledge manager needs a global perspective [Bartlett and Ghoshal (1992); Javidan et al. (2006)], has to link information from different disciplines, and acquires knowledge from external alliance partners [Zhang et al. (2010)].

The idea manager has to think up new things creatively [Fillis (2010)] to recognize and assess opportunities in a discovery process [McGrath and MacMillan (1995)]. He can use the information from the knowledge manager for agenda setting and shaping of the entrepreneurial process [Hornsby et al. (1993)]. He creates the match between the idea and the organizational strategy and design [Andrews (1987)]. To evaluate and select the opportunities, he has to check the feasibility, the economic potential and the fit to strategy [Block and MacMillan (1985)]. The idea manager can use creativity and thinking techniques [e.g. De Bono (1999)] or a disciplined and organized process [Drucker (1985)] to increase the flow of ideas. He has to think systematically about entering new markets and creating new products, services and industries [Kim and Mauborgne (2004)].

The innovation manager has to consider different contexts and different types of innovations [Lassen and Nielsen (2009)] to design the implementation of many ideas. He has to look for resources and guide the new idea through the stages of implementation [Cooper (2011)]. Therefore, he has to design the innovation process cross traditional company boundaries. He can use corporate laboratories for product engineering and development and acts in the field of nonroutine often separate from the day-to-day business [Narayanan (2001)]. He can focus internally on strategy, structure, processes, capabilities (organizational rejuvenation, business model reconstruction, strategic renewal, capitalizing on capabilities) or externally on products and markets (sustained regeneration, domain redefinition) in order to innovate [Ulrich and Smallwood (2004); Morris et al. (2008)], and execute new businesses [Govindarajan and Trimble (2005)].

The entrepreneurial manager in established businesses designs job-sharing, coordination and motivation within the businesses [Picot et al. (1997)]. He has to develop a clear picture of the external business system, the internal value chain and the costs added at each stage to reveal leverage points for cost reduction [Abell (1993); Hammer (2004)]. Therefore, he has to look at all floating activities of the value chain internally as well as across the organization to design transparent and efficient relationships inside the firm and with the network partners. The entrepreneurial manager as an internal consultant [Wright (2008)] in established businesses also has to create and improve the processes of the organization in a holistic way, in accordance with the strategy, to create value for customers and to adapt the organization to external change through learning and redesign of the processes. He designs its operations and the supply chain with a special focus on flexibility. This permits the organization to adapt quickly to a changing and risky business environment and to realize continuous improvements to reduce costs and to achieve 
efficiency [Kaluza and Blecker (2005)]. He optimizes, modifies or increases its existing activities and makes effective decisions to solve basic problems in its businesses. The entrepreneurial manager in established businesses has a strong focus on results and identifies what activities should be ceased [Drucker (1985)]. He makes decisions on outsourcing of value-chain activities and support activities, and creates formal and informal networks to integrate processes [Child (2005)].

The synergy manager designs job-sharing and job assignment, coordination and motivation between departments [Picot et al. (1997)], between subsidiaries and between the subsidiary and its parent organization [Birkinshaw (2000)]. He finds a balance between the short-term and the long-term planning in turbulent times [Block and MacMillan (1985); McGrath and MacMillan (1995)], as well as between the entrepreneurial benefits of decentralization and the benefits of recognizing and exploiting corporate synergies e.g. across product lines in any function or through sharing a common resource and knowledge [Abell (1993)]. He secures the organization's position in the future through building competencies and realizing entrepreneurial activities which need more resources than a single business unit has [Hamel and Prahaland (1994)]. He realizes synergies between entrepreneurial activities, as well as between new businesses and established businesses [Porter (2004)]. The synergy manager has to fulfill three strategic needs - - - efficiency, innovation, and adaptability - - - to realize business activities with reference to the changed context in which the businesses operate [Child (2005)].

The synergy manager structures effective organizations through the assignment of decision rights within the company, methods of rewarding individuals and the design of systems to evaluate the performance of individuals and units [Brickley et al. (2004)]. He has to set the boundaries of the whole organization (what businesses should it do) and to decide on what basis the organization should compete to determine the design of the internal organization. He creates long-term partnerships with customers and suppliers, links people in different parts of the internal organization and realizes a fit among the strategy, the organizational design and the relevant business environment through sorting out which of the identified opportunities the VELO should pursue [Roberts (2004)].

Holistic intrapreneurship requires fulfilling the five entrepreneurial roles in an integrated manner and in interaction with the external business environment. Thus, it is necessary to focus on the external business arena in the following section.

\subsection{Conceptual framework to illustrate the global business environment}

The VELO has to play the entrepreneurial roles in interplay and exchange with its external business environment which is in a permanent state of change. This brings new opportunities and risks as well as the need for adaptation in established businesses. Understanding today's global and dynamic business environment is essential for the VELO and it is a result of the entrepreneurial collection of meaningful information. A clear picture of the external business environment offers a foundation for thinking about the proactive and reactive entrepreneurial activities representing the result of the entrepreneurial creation of the future. To realize the entrepreneurial 


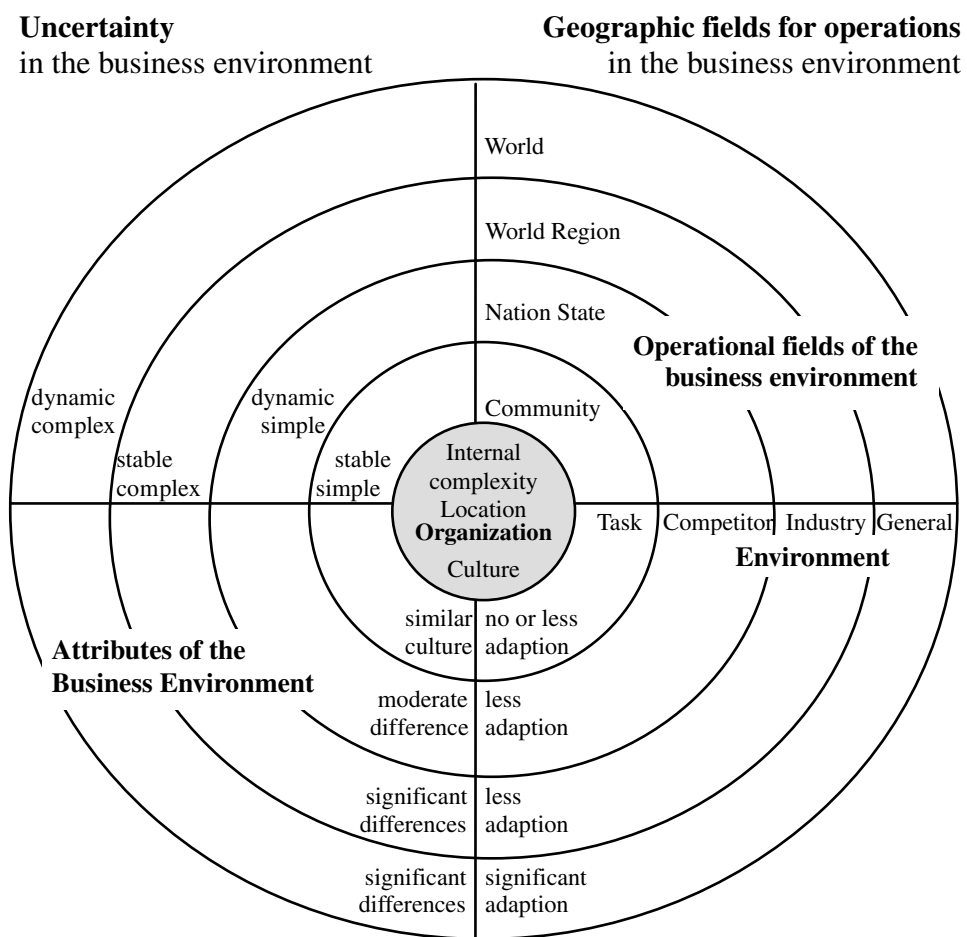

Diversity

of the business environment
Fields of influence and action

environment and organization

Fig. 6. A framework for the global business environment.

activities, it is necessary to design and adapt the internal business environment. The permanently changing business environment makes it necessary to continuously redesign the organizational architecture. A conceptual framework of the business environment (see Fig. 6) helps to create a specific mental model of the organization in its environment to act on the entrepreneurial roles and to pursue the entrepreneurial tasks.

In the literature, there are numerous concepts to describe and to analyze the business environment [e.g. Fahey and Narayanan (1986); Porter (2008)]. Some authors focus on the availability of resources for the organization [e.g. Emery and Trist (1965)], others on the attributes of the external environment like turbulence, hostility, complexity that determines uncertainty [e.g. Khandwalla (1977)] and diversity [e.g. Trompenaars and Hampden-Turner (1998)]. The internal business environment can be described in particular through processes [Porter (2004)], structures [Child (2005)] and other arrangements like strategy [Andrews (1987)], and culture [Schein (2003)]. A common distinction to define the fields of influence and interaction between the organization and its environment is made between a general (contextual) macro-environment and an immediate (operational) microenvironment [e.g. Hitt et al. (2005)]. This makes a systems view on the business environment very useful [e.g. Miller (1995)]. 
To get a holistic picture of the global business environment of a specific organization, it is supportive to define four dimensions. The first dimension focuses on the geographic areas in which the organization operates (global economy, world region, nation state, local community). The second dimension focuses on the fields for the operational interplay between the organization and its environment.

The relevant general macro-environment (political/legal, economic, sociocultural, technological, and physical segments) and the specific micro-environment (competitive or industry environment and the task environment of the organization) define these fields of influence and interaction for the exchange between the organization and its external business environment. The third and fourth dimensions focus on the attributes of uncertainty and diversity. The entrepreneurial organization has to assess the cultural diversity and the uncertainty of the business environment. This assessment has important implications for the required cultural adaptation of the entrepreneurial activities and the optimization of the organizational design in several geographic areas. Furthermore, entrepreneurial opportunities can be identified on the basis of cultural differences and the necessary intensity of the organization's entrepreneurial orientation [Miller (2011)] can be determined with particular reference to the dynamic of the external business environment [Morris et al. (2008)].

The conceptual framework presented (Fig. 6) can provide a VELO with a land map for analysis using an inside-outside-inside approach (see Fig. 7).

The creation of a symbiosis between the VELO and the external business environment requires an analysis and shaping of the networking between the organization and the environment. Thus, the following section focuses on the exploration of the relationship between the organization and the external business arena and presents a qualitative system model (via aggregation of the total system) to clarify the basic networking in the system explored.

\subsection{Qualitative model of a VELO}

Viewing the VELO as an open system [Miller (1995)], the entrepreneurial focus is on the exchange of inputs and outputs (products, services, information) between the organization and its macro- and micro-environment as well as on the internal adaptation of the organizational goals and architecture to support this exchange [Schrey“ogg (1995)].

The situation in the business environment determines the structure of the VELO [Child (2005)] to create entrepreneurial activities and to achieve a strategic fit between different parts of the organization as well as between the organization and its environment [Dess and Lumpkin (2003)]. The VELO acts to develop new competencies and resources to foster entrepreneurial activities induced through the top management as well as through decentral autonomous entrepreneurial behavior [Hitt et al. (2005)].

The entrepreneurial behavior of the organization [Zahra et al. (1999)] can be stimulated through a changing external business environment as well as through an internal dynamic [Bossel (2004)] based on factors like entrepreneurial strategy, 


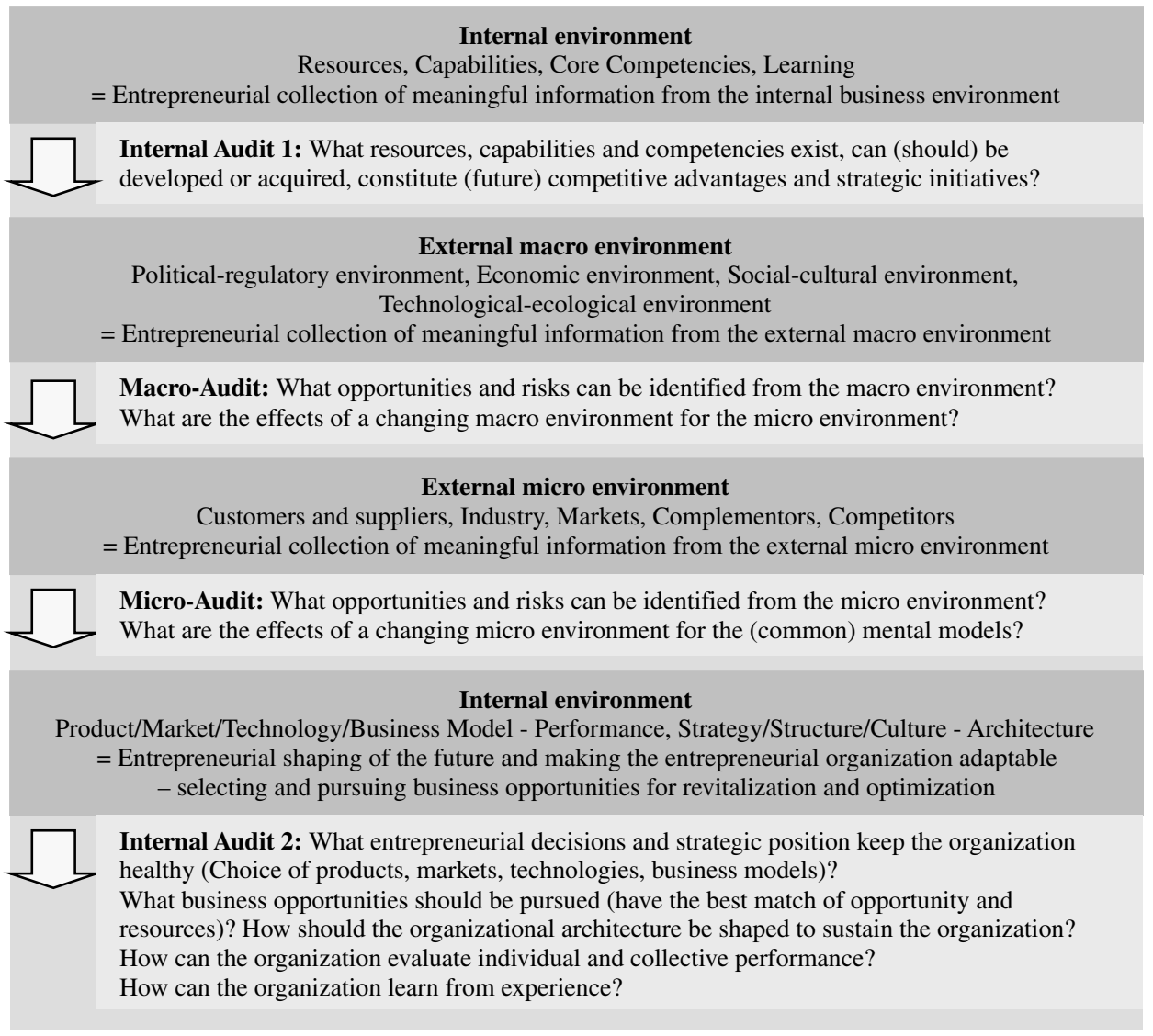

Fig. 7. Process model for implementation of the three entrepreneurial tasks.

structure, culture, resources and competencies. The entrepreneurial organization as a whole living organization learns about and adapts to the changing environment, builds sustainable and constructive relationships within the organization and with entities in the external business environment [De Geus (2002)].

From the systems, strategy and contingency literature [e.g. Probst (1987); Schrey“ogg (1995)], it is possible to deduce relevant variables for a qualitative model of the VELO and its business environment as a dynamic landscape for opportunities and risks. The entrepreneurial organization has to manage the exchange between the organization and the external environment in established and new businesses to stay vital, as well as to create an entrepreneurial posture as a momentum of its own.

The general macro-environment influences the industry and the competitive environment directly and the organizations operating in this industry more indirectly. The relevant micro-environment with industry, competitive and task environment interact with the VELO more directly [Platzek (2010)]. Changes in the microenvironment have an influence first on the entrepreneurial opportunities and threats in existing businesses. Here, optimization within existing businesses and thus efficiency improvements are at the forefront. VELOs react to increasing competitive 
pressure by the use of new technology for process innovations. In time, these bring about an improvement in cost efficiency and thus improved competitiveness in existing markets and with existing products.

Therefore, an important contribution is made to the short-term vitality of the organization. For the long-term vitality, it is necessary to identify the current situation and the upcoming changes and trends in the business environment and to develop existing or new markets with new products as quickly as possible. Competitors that follow in turn increase the competitive pressure such that in industries that are just establishing themselves, entrepreneurial activities for optimization become more and more necessary. To secure the long-term vitality of the organization in a dynamic environment, entrepreneurial organizations should continuously generate new and marketable products and develop new markets or new business models [Johnson et al. (2008)].

New opportunities in international markets result from globalization, although competitive pressure exhibits an increasingly global dimension. The top management and decentralized, autonomous entrepreneurial units [Reich (1987); Raes et al. (2011)] induce entrepreneurial activities [Heinonen (2007)]. These activities are coordinated and stimulated through the organizational design and the internal dynamics [Probst (1987)]. These internal entrepreneurial dynamics depend on:

(1) The strategic and entrepreneurial initiatives in established and new businesses and the evolution of the organization's mission over time;

(2) The entrepreneurial architecture with the formal and informal structures as well as the incentive and learning structures;

(3) The entrepreneurial culture with a focus on information, communication, cooperation, conflict resolution, innovation, learning, identification and motivation;

(4) The entrepreneurial exploitation and exploration of resources and competencies.

The qualitative model (see Fig. 8) links the entrepreneurial organization with its environment and presents the exchange through entrepreneurial activities in new and established businesses on a highly aggregated level. The model considers in a complementary way both variants for steering the entrepreneurial organization through entrepreneurial activities: the realization of decisions and measures is by instruction (in less complex environments) as well as by (guided) systemic evolutionary self-regulation [Probst (1987)].

The time lags via theoretical exploration introduced in the model reflect patterns in the real world, where there is no perfect information and information gathering and reactions need time. Systems thinking helps the VELO to be aware of such existing structures and archetypes [Senge (2006)]. In established business, the competitive and industry environment gives constant pressure for (lagging) adaptation (archetype shifting the burden); new businesses (lagging innovation) can be interpreted as the fundamental solution, but the schumpetrian gains of innovation attract new competitors (archetypical limits to growth) and brings (lagging) need for adaptation (the business evolves to an established business). 


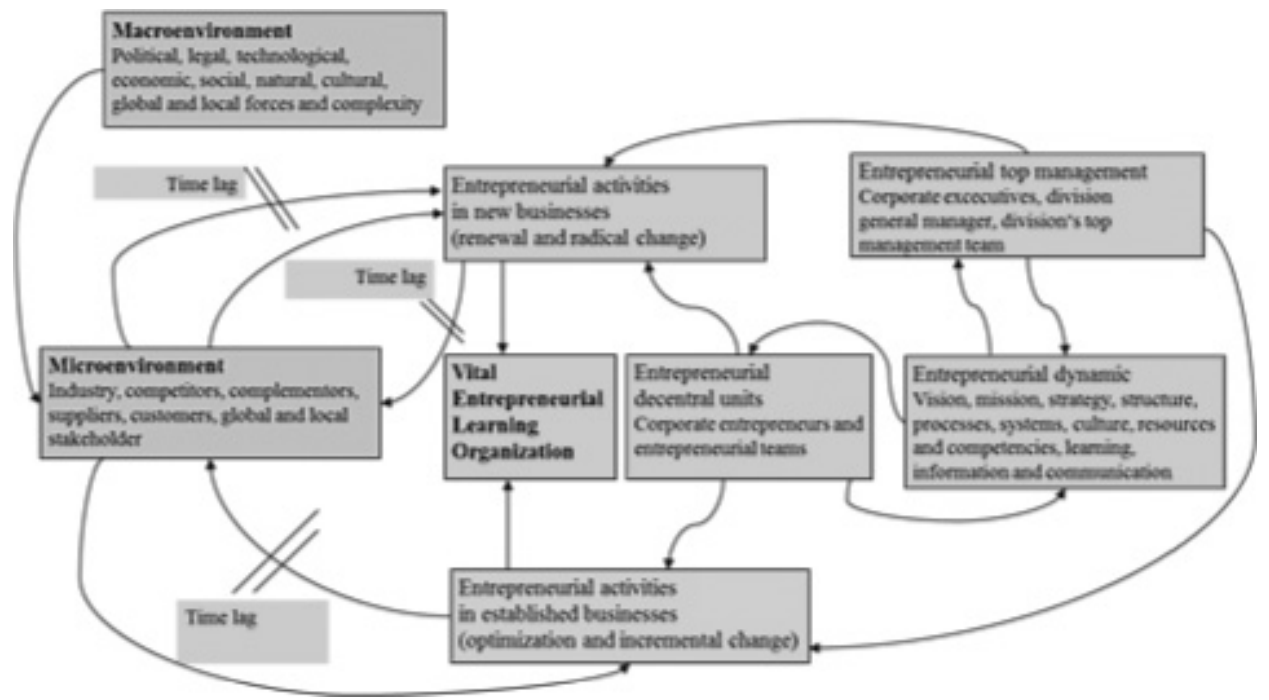

Fig. 8. Entrepreneurial change management: the chronically unfrozen VELO and the business environment.

In the following section, an outline for the development and strengthening of a VELO is introduced to complement the design concept for holistic intrapreneurship.

\subsection{Elements for strengthening entrepreneurial orientation}

The following five learning elements to trigger organizational learning processes are proposed to develop and support individual and organizational entrepreneurial orientation [see also McGinnis and Verney (1987)]. With a view to strengthening entrepreneurial culture and common mental models, the first element is a cultural analysis and an entrepreneurial cultural design involving managers and employees as cultural agents. The cultural agents analyze the development history of the organization, check which values and assumptions for securing vitality have to be adapted, develop common mental models of the organization and the external business environment and thus strengthen adaptability and an innovationsupportive culture.

A workshop for entrepreneurial shaping of the future is proposed as a building block for the holistic development of a VELO (second element). In the workshop, managers as change agents analyze and discuss identification and implementa-tion of business ideas, learn and develop common ideas for improvements that will strengthen holistic intrapreneurship. Central to this is the identification of opportunities, threats and potential synergies along with learning from each other and with each other - particularly from mistakes, so that organizational learning from entrepreneurial activities can ensue. In addition to technical learning and the question of what was done incorrectly or correctly, one can also ask why mistakes were made and why these were not corrected early enough [Argyris (1999)]. 
Block and MacMillan [1995] propose four working steps for individual and collective learning from entrepreneurial activities (third element). In the first step, documents relating to the most important events of an entrepreneurial activity are collected and chronologically documented in a log book (by entrepreneurial agents).

Subsequently, in the second step, the manager who is responsible for the activity, can be questioned with a view to establishing the origin of the business idea and its evaluation and record the market research process, the product development, the creation of the business plan, organization of the activity, incentive components, and the forming of basic assumptions about the environment. In the third step, a chronological history on the development of the entrepreneurial activity as well as of the main activities and critical decisions and events can be drawn up. In the fourth step, conclusions can be drawn for the future: what can be learned from the experience for future entrepreneurial activities?

To strengthen the outward orientation of an organization and its entrepreneurial actors, managers and employees can be deployed as country agents in the identification of opportunities and threats in the general macro-environment (fourth element) and also as industry agents in the development and analysis of strategic options in the specific micro-environment (fifth element). Industry agents can analyze the current and future competitive situation [see Porter (2008)] and the industry life cycle and also investigate industry-specific success factors [see Andrews (1987)]. The country agents (or even teams) can specify and evaluate a country (or several countries or economic regions) with the most important characteristics and fundamental framework conditions for globally active companies and with a global mindset [Srinivas (1995)]. Using mutual information, it is then possible to assess opportunities and threats jointly and develop organizational competencies [see Dess and Lumpkin (2003)] for various countries and from different economic regions.

Thus, it is possible to assess the political-legal systems, analyze the main economic factors and growth opportunities using economic indicators, or identify dynamic economic regions (clusters). Demographic or technological developments as well as social trends and cultural aspects can be evaluated bearing in mind potential

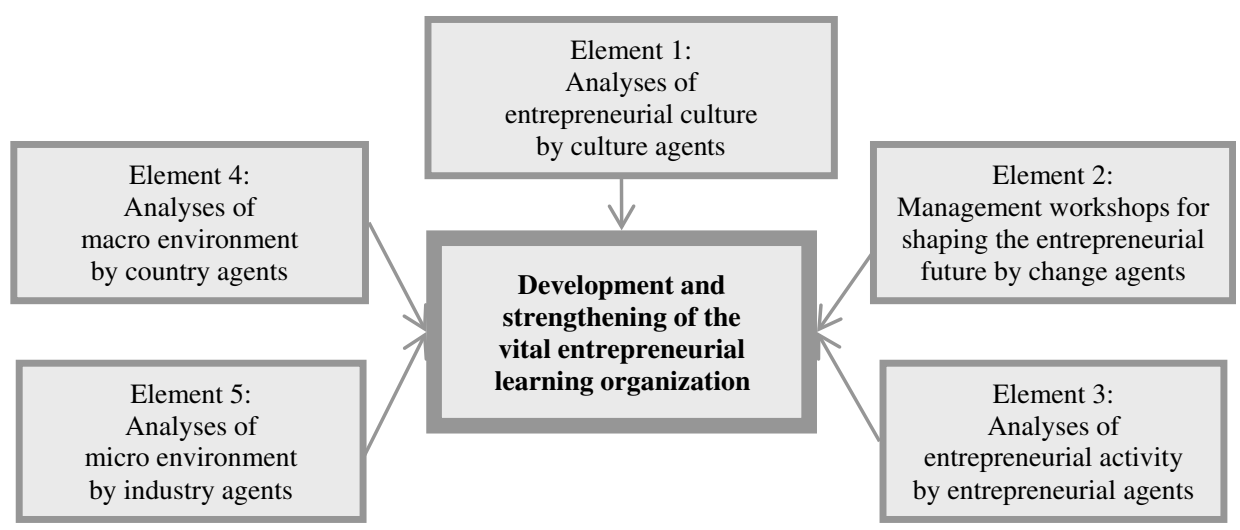

Fig. 9. Five elements for the development and strengthening of a VELO. 
entrepreneurial activities [see Fahey and Narayanan (1986)]. Using the five development-oriented building blocks (see Fig. 9), collective entrepreneurial information gathering and processing can be achieved, the necessary outward orientation can be developed, individual learning and organizational learning can be fostered, synergies can be created thus enabling the development and strengthening of holistic intrapreneurship in the context of the design concept that has been developed here for a VELO.

\section{Conclusion: Dynamic Fit in Today's Business Arena}

The VELO has to achieve a dynamic fit between the internal configuration and the strategic exchange with the specific external business environment. This concept of holistic intrapreneurship provides new insights for a better understanding of the role of intrapreneurship in today's business environment and for some implications for management practice. Based on a well-founded theory analysis, various theoretical fragments of intrapreneurship have been carried over by a theoretical exploration into an integrated framework (see Fig. 2). On the foundation of theoretical analysis of the three entrepreneurial tasks (see Fig. 3) identified, there follows the formulation of theoretical constructs (see Figs. 5-9) which together form a concept for holistic intrapreneurship. The basic theoretical constructs of the VELO are: nine design elements of holistic intrapreneurship, three entrepreneurial tasks, role model of the entrepreneurial organization, conceptual framework of the business environment and process model, qualitative systems model, the five elements to develop and strengthen the VELO. The role model of the entrepreneurial organization as a synthesis of the individual and collective approaches of intrapreneurship that are contained in the literature can provide the design of the VELO with an integrated orientation framework.

The conceptual framework developed here for the specification and analysis of the business environment can guide entrepreneurial gathering of meaningful information. The qualitative systems model focuses our understanding to help with entrepreneurial shaping of the future through exploitation and exploration. In implementing the three entrepreneurial tasks via the process model, the entrepreneurial organization must fulfill as a whole unit the roles of knowledge manager for opportunities and threats, idea finder, innovation manager (idea implementer), entrepreneurial manager in existing business and synergy manager. The conceptual framework for specification and analysis of the business environment can help to define the relevant areas of analysis of the business environment in specific situations such that future opportunities and threats can be proactively detected with an inside-outside-inside approach. The qualitative systems model sharpens the understanding of the elementary interaction between the VELO and the external environment in existing and new businesses and for adaptation, innovation and efficiency. As a result, internal and external impulses for the design of interactions on an aggregated level can be examined.

Holistic intrapreneurship requires learning by the actors, the teams and the whole organization and enables the necessary proactive, dynamic and creative adaptation 
to changes in the global environment, in particular by the realization of entrepreneurial opportunities and the processing of threats. Thereby, efficiency and flexibility must be strived for in existing businesses and new business and innovations must be developed in synergy with the external environment. Therefore, five development-oriented learning elements are proposed: management workshop for entrepreneurial shaping of the future by agents of change, analysis of individual entrepreneurial activities by entrepreneurial agents, analysis of entrepreneurial culture by culture agents, analysis of the macro-environment by country agents, analysis of the micro-environment by industry agents.

The characteristics of the business environment, in particular the degree of uncertainty and the cultural aspects [see Lee and Peterson (2000)] can be given thorough consideration in future business research using the concept of the VELO, defined by the presented theoretical constructs. On this basis, it is possible to give consideration to the specific design of a VELO in a specific context. In this respect, there emerge important research fields for future research projects. This would make it possible to investigate general design principles in specific environmental situations, particularly taking into account the dynamic, the complex and cultural features of alternative external environments and also giving consideration to organization types and sizes.

Future research can uncover important cross-cultural implications for the practical implementation of the holistic concept for intrapreneurship in specific contexts presented here. An in-depth examination of the transformation process for developing an entrepreneurial orientation and a study of the performance VELOs achieve in different business environments can also provide important clarification for practical implementation of a holistic concept of intrapreneurship. Further case study research can analyze practical problems in implementing and developing the VELO in a specific context. Thus, it is possible to identify firm-specific levers in business research projects to strengthen the entrepreneurial orientation and to meet the innovation challenges that differ from firm-to-firm [Hansen and Birkinshaw (2007)].

\section{References}

Abell, D. F. (1993). Managing with Dual Strategies: Mastering the Present, Pre-Empting the Future. The Free Press, New York.

Andrews, K. R. (1987). The Concept of Corporate Strategy, 3rd edn., Irwin, Illinois.

Argyris, C. (1999). On Organizational Learning, 2nd edn., Blackwell Publishers, Oxford.

Bartlett, C. A. and Ghoshal, S. (1992). What is a global manager? Harvard Business Review, 70, 5: 124-132.

Baumol, W. J. (2004). Entrepreneurial enterprises, large established firms and other components of the free-market growth machine. Small Business Economics, 23, 1: 9-21.

Biddle, B. J. and Thomas, E. J. (1966). Role Theory: Concepts and Research. John Wiley and Sons, New York.

Birkinshaw, J. (2000). Entrepreneurship in the Global Firm. Sage Publications, London.

Birkinshaw, J. and Gibson, C. (2004). Building ambidexterity into an organization. MIT Sloan Management Review, 45, 4: 47-55. 
Block, Z. and MacMillan, I. C. (1985). Milestones for successful venture planning. Harvard Business Review, 63, 5: 184-196.

Block, Z. and MacMillan, I. C. (1995). Corporate Venturing: Creating New Businesses Within the Firm. Harvard Business School Press, Boston.

Bossel, H. (2004). Systeme, Dynamik, Simulation: Modellbildung, Analyse und Simulation Komplexer Systeme. Books on Demand, Norderstedt (in German).

Bouchard, V. and Basso, O. (2011). Exploring the links between entrepreneurial orientation and intrapreneurship in SMEs. Journal of Small Business and Enterprise Development, 18, 2: 219-231.

Brickley, J. A., Smith, C. W. and Zimmerman, J. L. (2004). Managerial Economics and Organizational Architecture, 3rd edn., McGraw-Hill, New York.

Child, J. (2005). Organization: Contemporary Principles and Practice. Blackwell Publishing, Oxford.

Cooper, R. G. (2011). Winning at New Products: Creating Value Through Innovation, 4th edn., Basic Books, New York.

Covin, J. G. and Slevin, D. P. (1991). A conceptual model of entrepreneurship as firm behaviour. Entrepreneurship Theory and Practice, 16, 1: 7-25.

Covin, J. G. and Lumpkin, G. T. (2011). Entrepreneurial orientation theory and research: Reflections on a needed construct. Entrepreneurship Theory and Practice, 35, 5: 855-871.

Covin, J. G. and Wales, W. J. (2012). The measurement of entrepreneurial orientation. Entrepreneurship Theory and Practice, 36, 4: 677-702.

De Bono, E. (1999). Six Thinking Hats. Back Bay Books, New York.

De Geus, A. (2002). The Living Company: Habits for Survival in a Turbulent Environment. Harvard Business School Press, Boston.

Dess, G. G. and Lumpkin, G. T. (2003). Strategic Management: Creating Competitive Advantages. McGraw-Hill, New York.

Drucker, P. F. (1985). The discipline of innovation. Harvard Business Review, 63, 3: 67-72.

Drucker, P. F. (1994). The theory of the business. Harvard Business Review, 72, 5: 95-104.

Emery, F. E. and Trist, E. L. (1965). The causal texture of organizational environments. Systems Thinking, ed. F. E. Emery. Penguin Books, Middlesex.

Fahey, L. and Narayanan, V. K. (1986). Macroenvironmental Analysis for Strategic Management. West Publishing Company, St. Paul.

Fillis, I. (2010). The role of creativity in entrepreneurship. Journal of Enterprising Culture, 18, 1: 49-81.

Forgang, W. G. and Einolf, K. W. (2007). Management Economics: An Accelerated Approach. M. E. Sharpe, New York.

Garvin, D. A. and Levesque, L. C. (2006). Meeting the challenge of corporate entrepreneurship. Harvard Business Review, 84, 10: 102-112.

Govindarajan, V. and Trimble, C. (2005). Building breakthrough businesses within established organizations. Harvard Business Review, 83, 5: 58-68.

Greiner, L. E. (1998). Evolution and revolution as organizations grow. Harvard Business Review, 76, 3: 55-67.

Gupta, A. K. and Govindarajan, V. (2002). Cultivating a global mindset. Academy of Management Executive, 16, 1: 116-126.

Guth, W. D. and Ginsberg, A. (1990). Guest editor's introduction: Corporate entrepreneurship. Strategic Management Journal, 11, 4: 5-15.

Hamel, G. and Prahaland, C. K. (1994). Competing for the Future. Harvard Business School Press, Boston.

Hamel, G. (2006). The why, what, and how of management innovation. Harvard Business Review, 84, 2: 72-84.

Hammer, M. (2004). Deep change: How operational innovation can transform your company. Harvard Business Review, 82, 4: 85-93. 
Hansen, M. T. and Birkinshaw, J. (2007). The innovation value chain. Harvard Business Review, 85, 6: 121-130.

Heinonen, J. (2007). Approaching a deeper understanding of corporate entrepreneurship: Focusing on co-evolutionary processes. Journal of Enterprising Culture, 15, 2: $165-186$.

Heisig, P. (2009). Harmonisation of knowledge management - Comparing $160 \mathrm{KM}$ frameworks around globe. Journal of Knowledge Management, 13, 4: 4-31.

Hills, G. E., Hultman, C. M. and Miles, M. P. (2008). The evolution and development of entrepreneurial marketing. Journal of Small Business Management, 46, 1: 99-112.

Hitt, M. H., Ireland, R. D. and Hoskisson, R. E. (2005). Strategic Management: Competitiveness and Globalization. Thomson, Mason.

Homann, K. and Suchanek, A. (2005). Ökonomik: Eine Einführung, 2nd edn., Mohr Siebeck, Tübingen.

Hornsby, J. S., Naffziger, D. W., Kuratko, D. F. and Montagno, R. V. (1993). An interactive model of the corporate entrepreneurship process. Entrepreneurship Theory and Practice, 12, 2: 29-37.

Ireland, R. D., Covin, J. G. and Kuratko, D. F. (2009). Conceptualizing corporate entrepreneurship strategy. Entrepreneurship Theory and Practice, 33, 1: 19-46.

Jackson, M. C. (2000). Systems Approaches to Management. Kluwer Academic/Plenum Publishers, New York.

Jackson, M. C. (2006). Creative holism: A critical systems approach to complex problem situations. Systems Research and Behavioral Science, 23, 5: 647-657.

Javidan, M., Dorfman, P. W., Luque, M. S. D. and House, R. J. (2006). In the eye of the beholder: Cross-cultural lessons in leadership from Project GLOBE. Academy of Management Perspectives, 20, 1: 67-90.

Johnson, M. W., Christensen, C. M. and Kagermann, H. (2008). Reinventing your business model. Harvard Business Review, 86, 12: 50-59.

Kaluza, B. and Blecker, T. (2005). Erfolgsfaktor Flexibilität: Strategien und Konzepte für Wandlungsfähige Unternehmen. Erich Schmidt Verlag, Berlin (in German).

Kanter, R. M. (2006). Innovation: The classic traps. Harvard Business Review, 84, 11: 73-83.

Khandwalla, P. N. (1977). The Design of Organizations. Harcourt Brace Jovanovich, New York.

Kim, W. C. and Mauborgne, R. (2004). Blue ocean strategy. Harvard Business Review, 82, 19: $76-84$.

Kotter, J. P. (2012). Accelerate. Harvard Business Review, 90, 11: 43-58.

Lassen, A. H. and Nielsen, S. L. (2009). Corporate entrepreneurship: Innovation at the intersection between creative destruction and controlled adaptation. Journal of Enterprising Culture, 17, 2: 181-199.

Lee, S. M. and Peterson, S. I. (2000). Culture, entrepreneurial orientation, and global competitiveness. Journal of World Business, 35, 4: 401-416.

Lumpkin, G. T. and Dess, G. G. (1996). Clarifying the entrepreneurial orientation construct and linking it to performance. Academy of Management Review, 21, 1: 135-172.

March, J. G. (1991). Exploration and exploitation in organizational learning. Organization Science, 2, 1: 71-87.

McGinnis, M. A. and Verney, T. P. (1987). Innovation management and intrapreneurship. SAM Advanced Management Journal, 52, 3: 19-23.

McGrath, R. G. and MacMillan, I. C. (1995). Discovery-driven planning. Harvard Business Review, 73, 4: 44-54.

Miller, D. (2011). A reflection on EO research and some suggestions for the future. Entrepreneurship Theory and Practice, 35, 5: 873-894.

Miller, J. G. (1995). Living Systems. University Press of Colorado, Niwot.

Mintzberg, H. (1991). Five Ps for strategy. The Strategy Process: Concepts, Contexts, Cases, eds. H. Mintzberg and J. B. Quinn. Prentice-Hall International, London. 
Morris, M. H., Kuratko, D. F. and Covin, J. G. (2008). Corporate Entrepreneurship and Innovation: Entrepreneurial Development Within Organizations, 2nd edn., Thomson South-Western, Mason.

Narayanan, V. K. (2001). Managing Technology and Innovation for Competitive Advantage. Prentice Hall, New Jersey.

Narayanan, V. K. and Fahey, L. (2004). Invention and navigation as contrasting metaphors of the pathways to the future. Managing the Future: Foresight in the Knowledge Economy, eds. H. Tsoukas and J. Shepherd. Blackwell Publishing, Oxford.

O'Reilly III, C. A. and Tushman, M. L. (2004). The ambidextrous organization. Harvard Business Review, 82, 4: 74-81.

Picot, A., Dietl, H. and Franck, E. (1997). Organisation: Eine Ökonomische Perspektive. Schäffer-Poeschel Verlag, Stuttgart (in German).

Pinchot, G. (1988). Intrapreneuring: Mitarbeiter als Unternehmer. Gabler Verlag, Wiesbaden (in German).

Platzek, B. P., Pretorius, L. and Winzker, D. H. (2010). A role model for entrepreneurial firms in a global business environment. Business and Management - Selected Papers, Vol. II, eds. R. Ginevičius, A. V. Rutkauskas and R. Počs. VGTU Publishing House Technika, Vilnius, pp. 476-487.

Platzek, B. P., Pretorius, L. and Winzker, D. H. (2011). Identifying and pursuing business opportunities in a vital entrepreneurial learning organisation, in Innovative Systems Thinking: Unravelling Complexity for Successful Solutions. ISEM 2011 Proceedings, eds. C. S. L. Schutte and L. Pretorius, Stellenbosch, 21-23 September.

Platzek, B. P., Hohl, E. K. and Pretorius, L. (2013). General manager roles in the vital entrepreneurial learning organization, in Innovating in Global Markets: Challenges for Sustainable Growth. XXIV ISPIM Proceedings, Helsinki, pp. 1-27.

Porter, M. E. (2004). Competitive Advantage: Creating and Sustaining Superior Performance. Free Press, New York.

Porter, M. E. (2008). The five competitive forces that shape strategy. Harvard Business Review, 86, 1: 79-93.

Probst, G. J. B. (1987). Selbst-Organisation: Ordnungsprozesse in Sozialen Systemen aus Ganzheitlicher Sicht. Verlag Paul Parey, Berlin (in German).

Raes, A. M. L., Heijltjes, M. G., Glunk, U. and Roe, R. A. (2011). The interface of the top management team and middle managers: A process model. Academy of Management Review, 36, 1: 102-126.

Reich, R. B. (1987). Entrepreneurship reconsidered: The team as hero. Harvard Business Review, 65, 3: 77-83.

Roberts, J. (2004). The Modern Firm: Organizational Design for Performance and Growth. Oxford University Press, Oxford.

Roffe, I. (1999). Innovation and creativity in organisations: A review of the implications for training and development. Journal of European Industrial Training, 23, 4/5: 224-237.

Schein, E. H. (1995). Kurt Lewin's change theory in the field and in the classroom: Notes toward a model of managed learning. Systems Practice, Working Paper 3821, pp. 1-33.

Schein, E. H. (2003). Organisationskultur: The Ed Schein Corporate Culture Survival Guide. EHP, Bergisch Gladbach (in German).

Schindehutte, M., Morris, M. H. and Kocak, A. (2008). Understanding market-driving behavior: The role of entrepreneurship. Journal of Small Business Management, 46, 1: $4-26$.

Schreyögg, G. (1995). Umwelt, Technologie und Organisationsstruktur: Eine Analyse des Kontingenztheoretischen Ansatzes, 3rd edn., Bern, Haupt (in German).

Senge, P. M. (2006). The Fifth Discipline: The Art and Practice of the Learning Organization. Random House, London.

Srinivas, K. M. (1995). Globalization of business and the third world: Challenge of expanding the mindsets. Journal of Management Development, 14, 3: 26-49. 
Trompenaars, F. and Hampden-Turner, C. (1998). Riding the Waves of Culture: Understanding Cultural Diversity in Global Business, 2nd edn., McGraw-Hill, New York.

Tushman, M. L. and O'Reilly III, C. A. (1996). Ambidextrous organizations: Managing evolutionary and revolutionary change. California Management Review, 38, 4: 8-30.

Ulrich, D. and Smallwood, N. (2004). Capitalizing on capabilities. Harvard Business Review, 82, 6: 119-127.

Vester, F. (2007). The Art of Interconnected Thinking: Tools and Concepts for a New Approach to Tackling Complexity. MCB Verlag, München.

Wright, C. (2008). Inside out? Organizational membership, ambiguity and the ambivalent identity of the internal consultant. British Journal of Management, 20: 309-322.

Zahra, S. A., Jennings, D. F. and Kuratko, D. F. (1999). The antecedents and consequences of firm-level entrepreneurship: The state of the field. Entrepreneurship Theory and Practice, 24, 2: 45-65.

Zhang, H., Shu, C., Jiang, X. and Malter, A. J. (2010). Managing knowledge for innovation: The role of cooperation, competition, and alliance nationality. Journal of International Marketing, 18, 4: 74-94.

\section{Biography}

Bernd Peter Platzek has over 20 years of experience in management in the education and engineering environment (university and industry). He was several years Managing Director of the Baden-Wuerttemberg Chamber of Engineers. He received his Ph.D. from the University of Pretoria. He is Lecturer in Economics, Management and Entrepreneurship at the Ravensburg-Weingarten University of Applied Sciences (HRW) since 2005, at the Baden-Wuerttemberg Cooperative State University (DHBW) since 2010 and Researcher in the Graduate School of Technology Management at the University of Pretoria since 2012. He is Director Executive Programmes at the HRW and Managing Director of an independent record label. He has published various conference papers and peer-reviewed journal articles as author and co-author in the fields of entrepreneurship, innovation, leadership and management. He has supervised more than 30 master students in international business and technology management. He is Member of the German Association of Political and Business Economists (BDVB), Member of GEMA and Member of the Federal Music Industry Association (BVMI).

Leon Pretorius has more than 37 years professional, engineering, academic, and academic management experience. He received the degrees B.Sc. Eng., B.Sc. Eng. Hons. and M.Sc. Eng. (all cum laude) in Mechanical Engineering in 1977, 1978 and 1979, the B.Sc. Hons. and M.Sc. in Mathematics (both cum laude) in 1980 and 1982 as well as the Doctor of Engineering (D Eng.) in 1983 from the University of Pretoria, South Africa. He was Professor at the University of Johannesburg, South Africa until 2007. In 2004 he was the last Dean of Engineering at the Rand Afrikaans University (RAU) prior to the merger of RAU and TWR when he became Executive Dean of Engineering and the Built Environment at the University of Johannesburg in 2005. He is currently Professor in the Graduate School of Technology Management at University of Pretoria. He has concurrently been active as Specialist Consultant and Researcher in engineering industry since 1980. He has supervised more 
than 170 Master and Ph.D. students in engineering as well as engineering and technology management. He has also published more than 180 technical conference papers and peer-reviewed journal articles as author and co-author in his fields of expertise. He is an Honorary Fellow of SAIMechE, Member of SAIIE, Member of ASME and Member of IEEE. He is rated as Researcher by the National Research Foundation (NRF) in South Africa.

Dietmar Hans Winzker has gained extensive technical and managerial experience over more than 20 years in the design, development and management of complex, high tech engineering systems. He worked in a large (27 000 employees) SA Corporation charged with Acquisition and Development of Home-Grown Defence Systems where he became a Senior Manager. Initially he contributed on missile and rocket technology, later he was in charge of the technical integrity of the $155 \mathrm{~mm}$ Artillery Systems. He also led technical and management teams in "catastrophic failure" investigations from time-to-time. With this solid background, from 1990 onwards he started off as an international Business Facilitator and Consultant for multi-disciplinary teams in diverse industry sectors, specialising in areas such as system engineering, business transformation, human capacity development and business leadership, working on four Continents. He initially studied electronics and later aeronautical engineering. He holds a number of engineering degrees which culminated in a Ph.D. in engineering in 1988. In recognition of his extensive experience and ability, he was appointed Professor Extraordinary by the Faculty of Engineering of the University of Pretoria, Department of Engineering and Technology Management during 1995. With his interest and experience in senior management he worked on a second doctorate in Engineering and Technology Management which was conferred to him by the University of Johannesburg in 2005. He teaches post-graduate short courses regularly at a number of South African universities and at a German university in subjects as diverse as system engineering, development of strategic intent for a post-modern world, personal competencies for management development, intercultural management and marketing, system health methodology (a management topic) and business leadership development. He facilitates in-house workshops and seminars in diverse companies internationally (mainly Europe and USA but also South Africa) has presented papers and seminars at conventions and conferences. He has published numerous peer-reviewed papers, as author and co-author, in technology management and presented them at international conferences. 